\title{
Some Observations on Modern Chinese Confucianism
}

KIRSTEN RØNBØL LAURIDSEN

The Royal Library, Copenhagen

\begin{abstract}
About thirty years ago Yang Mo's novel The Song of Youth was made into a movie portraying young people committed to change and revolution. In the ideological confusion one sentence rang out very clearly, as the words of Maxim Gorky were used to express the essence of Chinese culture: "In this world the most glorious thing is to be a man" (Zai shijieshang zui guangrong de shi jiu shi zuo yige ren).
\end{abstract}

The death of Mao and the change of political environment was the starting point for a new way of thinking. Mao's political and ideological role has been delicately dealt with by trying to preserve the legitimacy of the revolution while discarding some of the basic elements of Mao Zedong-thought. The next move has been to look towards traditional Chinese philosophy to serve ideological development and national pride.

\section{The Chinese Philosophical Heritage}

An effort was made by Zhang Dainian in an article published in Zhexue Yanjiu in 1979 entitled "On the Critical Inheritance of Philosophical Thought". 1 Making use of a thorough knowledge of Marxist classics and very apt quotations mainly from Hegel and Engels, he was able to reach conclusions supporting the theory proposed by Feng Youlan in the 1950s, that statements in classical philosophy, as those of Confucius, had an abstract meaning making them forever relevant, besides the concrete meaning limited by the historical circumstances. In his view, however, by far the most important issue was actually to make use of the valuable parts of Chinese culture in tackling philosophical problems. He carefully and cautiously defines the essence of the old culture as follows:

All ideas that reflect to a definite degree the actual circumstances of the objective world and its objective laws are scientific ideas. All those ideas 
that reflect to a definite degree the demands of the masses of the people and the demands of social progress are democratic, revolutionary ideas. ${ }^{2}$

Such a definition would cover quite a good deal of the Chinese philosophical heritage.

Zhang Dainian maintains that although the form of classical materialist philosophy may be outdated, it still has a content of excellence, and that in taking over the legacy of ancient philosophy one should not be limited to inheriting the abstract meanings of philosophical propositions. Hestresses the view that in studying philosophy, one should not study for the sake of study but "in order to discover and establish its importance and significance to socialist culture". ${ }^{3}$

Such views do not really disagree with the official approach to the intended role of ideology in the period of developing socialism with elements of capitalism added - but without any too liberal ways of thinking.

The official approach has been presented in philosophical terms by $\mathrm{Wu}$ Yuanliang in an article called "On the Coordinated Development of Spiritual and Material Civilizations", 4 published in Zhexue Yanjiu some three years later than Zhang's article. He calls this concept of coordinated development of spiritual and material civilizations a "scientific summation of the international communist movement" and "our Party's creation and development of the theory of scientific communism." The article is an attempt to outline this theory but actually the author does not get much further than affirming that such a coordination is a good and necessary thing. It does not really touch upon how such a coordinated development might be brought about.

The author does, however, make some interesting observations as to the futility of expecting material development to produce spiritual progress, whereas spiritual development would boost the creation of material wealth. States Wu:

Obviously, improvement and raising the standard of material life does not spontaneously boost the level of people's ideological awareness. ${ }^{5}$

Only a revolutionary ideal can develop and improve this ideological awareness. As victory in revolution has been won, and the realization of communist society is some generations ahead, it would indeed, as pointed out by Stuart Schram, "be desirable to put forward some immediate vision capable of giving meaning to social activity during the next decade or so."6

This is a serious and vital task, because as Wu Yuanliang puts it: 
For the managers and controllers of society to effectively manage and control a social system, they must rely on practical material strength and conceptual spiritual strength as well. ${ }^{7}$

It does not seem that much helpful material for such spiritual strength of a new order could be found with an iconoclast political philosopher like Mao Zedong who considered dogmatic thinking in any form or shape as being of very little use. Mao's philosophy has actually been summed up in Zhexue Yanjiu by Xue Zhen. In "On the Difference between 'One Divides into Two' and 'Two Come into One" in 1979,8 he says that it is quite clear that Mao considered the law of the unity of opposites, that one divides into two, a world outlook or a world view.

Comrade Mao Zedong said that materialist dialectic is the scientific methodology of Marxism, its epistemological method, its theoretical methodology, and its world outlook. To regard the universe as fundamentally a developing material universe is a world outlook; to in turn use this world view to observe the universe, to study problems in the universe, to lead a revolution, to carry out one's work, to engage in production, to direct a battle, to examine the strengths and shortcomings of people, this is a methodology. There is no separate independent methodology beyond this. Thus in the hands of Marxists, our world view and methodology are a single thing. ${ }^{9}$

In this essay it is suggested that elements of modern Neo-Confucian thought, as found in the creative philosophical writings of Feng Youlan, might be of more interest to modern Chinese leaders. Confucianism could cultivate human initiative and creative ability, leading them into the only form where they could find their proper expression. It would further appeal to an influential segment of Chinese intellectuals and Chinese patriots at home or abroad. It is interesting to note that while humanism is not entirely out of favour in authoritative circles, bourgeois humanism has been singled out for explicit disapproval.

The question of an ideological framework for modern Chinese society poses a variety of problems. In the widely circulated version of Mao Zedongthought which held sway during the Cultural Revolution a main theme was wei gong (for society as a whole), but although the Confucian connotations were present it was not quite the Confucian concept. The selfless conduct of a Lei Feng did not leave him any personal judgement, somebody else decided 
what was for the common good. The moral values attached to his behaviour were decided by the Party and the state. Once these exalted authorities were admitted to have been wrong on important issues, the standard could no more be upheld. Today much effort is devoted to the task of finding a common ideological denominator worked out on the basis of the Chinese cultural heritage combined with Marxism-Leninism. Compared to this, Confucian values tend to take on new life as they stand out in their fundamental simplicity and inherent integrity, once more affirming that in order to be a man you have to cope with social relations. The prerequisite for moving with ease in society is the proper handling of social relations. Social affairs are human affairs. To handle human affairs correctly one has to study to become a person able to handle life, one has to study with a view to changing one's ways and improving one's understanding; that is why Confucianists insist that study is wei ji (for yourself), so as to ensure that one's behaviour may be wei gong (for the public).

It is interesting to see the efforts to establish a new morality in contemporary China, but it is no less interesting to see Chinese Confucianists all over the world, China included, raising the eternal standards.

\section{Third-Phase Confucianism}

A bid for a third phase development of Confucianism has been tentatively made in a lecture at Beijing University by Tang Yijie called "An Enquiry into the Possibility of a Third-Phase Development of Confucianism". ${ }^{10}$

The first phase of Confucianism is, of course, "the school of thought advocated by Confucius, Mencius, and Xunzi during the Spring and Autumn period and the Warring States."11 The second phase is the Song and Ming NeoConfucian school of idealist philosophy which emerged under the impact of Buddhist ideas. This school greatly pushed forward the Confucian doctrines.

Over the last century, Western civilization has found its way into China. Especially around the time of the May Fourth movement Marxism was also disseminated into our country. That gave an even bigger and more serious impact on China's traditional thought and culture. Under such circumstances, is it possible for Confucianism to have a third-phase development? Can it be brought back to life? Can it still have a role to play in China and the world? ${ }^{12}$ 
In Tang's view an important element of third-phase Confucianism would be the concept of an ideal society towards which all good men must strive:

According to the Confucians, an ideal society is an ideal which has the possibility, not the necessity of being realized. Despite the fact that an ideal society has never been realized before, it is a matter of fundamental importance, a problem of one's attitude toward life, whether or not one should seek to realize it. It is the Confucian's belief that one should ceaselessly seek after it. ${ }^{13}$

Even if this ideal may not necessarily come true, the Confucian will bear in mind a picture of such an ideal society. This ideal may, of course, be called communist society; but Tang Yijie does not do so.

Third-phase Confucians would further agree with the view-point presented by Wu Yuanliang that man cannot take his cue for selfless striving merely from his present social environment. Man must have an ideal:

That Confucianism still has a value for its continued existence is perhaps due to the sole fact that it provides us with a reason for being a man. It is most difficult for one to be a man, still more to maintain a harmony between oneself and nature, society and others, or between one's inside and outside in body and soul. Is such a requirement unnecessary in today's world? As Confucianism only tells us the reason for being a man, we should not set demands on it in other respects. And it should come as no surprise that it suffers from some inadequacies. ${ }^{14}$

Modern Confucians seem to say that one may win victory in revolution with the help of Marxism, when fighting for a common goal gives reason for selfsacrifice, supports discipline and encourages man to help his comrades in a spirit of brotherhood. However, when it comes to the building of society and waiting and working all the dreary years until the realization of the goal of communism, one may be in need of some spiritual support such as that of Confucianism:

As the mainstream of China's traditional philosophy, thinking and culture, the Confucian philosophy has sustained today an even heavier impact than in the past. After we have made a profound criticism of it, we are now reexamining its value. Is it impossible that it can establish, under the new impact, a new system of its own logic and theory of knowledge? Traditional Chinese philosophy should have a third-phase development. $^{15}$ 
Tang Yijie does not suggest that the present version of a socialist system is the root of alienation, he only offers a way to overcome alienation. Like Feng Youlan he maintains that man is not only a part of society but also of the universe and that Heaven must be integrated with man.

It might not be an easy task to integrate such views with a wholehearted dedication to the affairs of state, but it has been done before in Chinese history, and Feng Youlan suggested the way in putting forward his theory on the NeoConfucian Way and the concept of selflessness.

In what may be regarded as a final summing up of the contents and role of Neo-Confucian philosophy, Feng Youlan says:

Neo-Confucianism may be called "the learning of man". It deals with such topics as man's place and role in the universe, the relation between man and nature, and the relations between man and man and between human nature and human happiness. Its aim is to achieve unity of opposites in the life of man, and to show how to accomplish this. ${ }^{16}$

Feng Youlan is actually describing the essence of his own philosophy, when he sets out the meaning of the basic Confucian concept ren (humanity, benevolence):

The Neo-Confucianists considered benevolence (humanity, ren) as the first of Four Fundamental Virtues, or even including all four. Benevolence means love for others. The man who loves others is called "the benevolent man". According to Neo-Confucianism the spiritual world of the benevolent man merges into a whole with the universe. He considers all men as his brothers and everything as his companion. The Chinese word for "benevolence" and for "man" (ren) have the same sound. In the Classics, the two words mutually defined each other. The learning of man may thus be defined as the learning of benevolence. According to NeoConfucianism, when this kind of unity is achieved, there comes supreme happiness. It is a kind of happiness different in quality from sensuous pleasures. It is an enjoyment of emancipation and freedom from the boundaries and limitations of particularity and subjectivity. It is an emancipation - not in the political sense, but an emancipation from the finite to the infinite, from time to eternity. What Kant said about the three important matters in the world of noumena - God, immortality, and freedom - is similar. ${ }^{17}$

Such superior happiness may be called intellectual happiness, because 
it is the result of the activity of the intellect. It differs in quality from sensuous pleasures resulting from the satisfaction of the sense organs. In order to achieve this state, one does not have to do anything special, to leave society or abandon one's family. Nor is there need for worship and prayer. One just fights against selfishness. That is all. In this way, the "this side" becomes the same as as the "other side", the "other side" resides in the "this side". This synthesis is the contribution of Neo-Confucianism toward the development of the human intellect and the advancement of human happiness. ${ }^{18}$

\section{Concluding Remarks}

The future of Confucianism in China is not only a question of the attitude of the present Chinese government. The enduring power of an ideology is closely associated with the quality of its inherent values and its ability to cope with a changing social environment while still preserving them.

Confucianism has so far proved itself strong enough to keep its hold on men of integrity who have shown their mettle even in the storms of revolutionary change. When Feng Youlan developed his theories of transcending Confucian philosophy between the two world wars, he brought Confucianism several stages ahead of modern society. As he remained a steadfast Confucian in the difficult years before and during the Cultural Revolution, he greatly contributed to the preservation of Confucian thinking as an integrated part of modern Chinese ideology. The immediate future of Confucianism in China will depend much more on the philosophical contents of new Confucianism rather than shifting political attitudes.

Kirsten Rønbol Lauridsen is Acting Head, Oriental Department, Royal Library, Copenhagen 


\section{NOTES}

1 Zhang Dainian, "Lun zhexue sixiang de pipan jicheng", Zhexue Yanjiu, 1979, No. 9, pp. 33-39.

2 Quoted from Zhang Dainian, "On the Critical Inheritance of Philosophical Thought", Chinese Studies in Philosophy, Vol. 12, No. 2 (1980-81), p. 61.

3 lbid., p. 65.

$4 \mathrm{Wu}$ Yuanliang, "Lun jingshen wenming he wuzhi wenming de xietiao fazhan", Zhexue Yanjiu, 1982, No. 12, pp. 7-12.

5 Ibid., p. 72.

6 Stuart R. Schram, Ideology and Policy in China Since the Third Plenum, 1978-84 (London: Contemporary China Institute, SOAS, 1984), p. 36.

7 Quoted from Wu Yuanliang, "On the Coordinated Development of Spiritual and Material Civilizations", Chinese Studies in Philosophy, Vol. 15, No. 1 (1983), p. 65.

8 Xue Zhen, "Guanyu 'yi fen wei er' yu he er er yi' de fenqi", Zhexue Yanjiu, 1979, No. 8, pp. 21-27.

9 Quoted from Xue Zhen, "On the Difference Between 'One Divides Into Two' and Two Combine Into One"', Chinese
Studies in Philosophy, Vol. 12, No. 1 (1980), p. 7.

10 Tang Yijie, "Guanyu rujia sixiang di san qi fazhan kenengxing de tantao", Beijing Daxue.

11 Quoted from Tang Yijie, "An Inquiry into the Possibility of a Third-Phase Development of Confucianism", Chinese Studies in Philosophy, Vol. 15, No. 2 (1983-84), p. 3.

12 Ibid.

13 Ibid., p. 4.

14 Ibid., p. 8.

15 Quoted from Tang Yijie, "Prospects for the Study of the History of Chinese Philosophy: Also on the Issue of the True, the Good, and the Beautiful in China's Traditional Philosophy", Chinese Studies in Philosophy, Vol. 15, No. 2 (198384), p. 24.

16 Fung Yu-lan, "A General Statement on Neo-Confucianism", in Chan Wing-tsit (ed.), Chu Hsi and Neo-Confucianism (Honolulu: University of Hawaii Press, 1986), p. 21.

17 lbid., p. 24.

18 lbid. 